\title{
Modern antimicrobial therapy in dental caries
}

\author{
Terapia antimicrobiană modernă în caria dentară
}

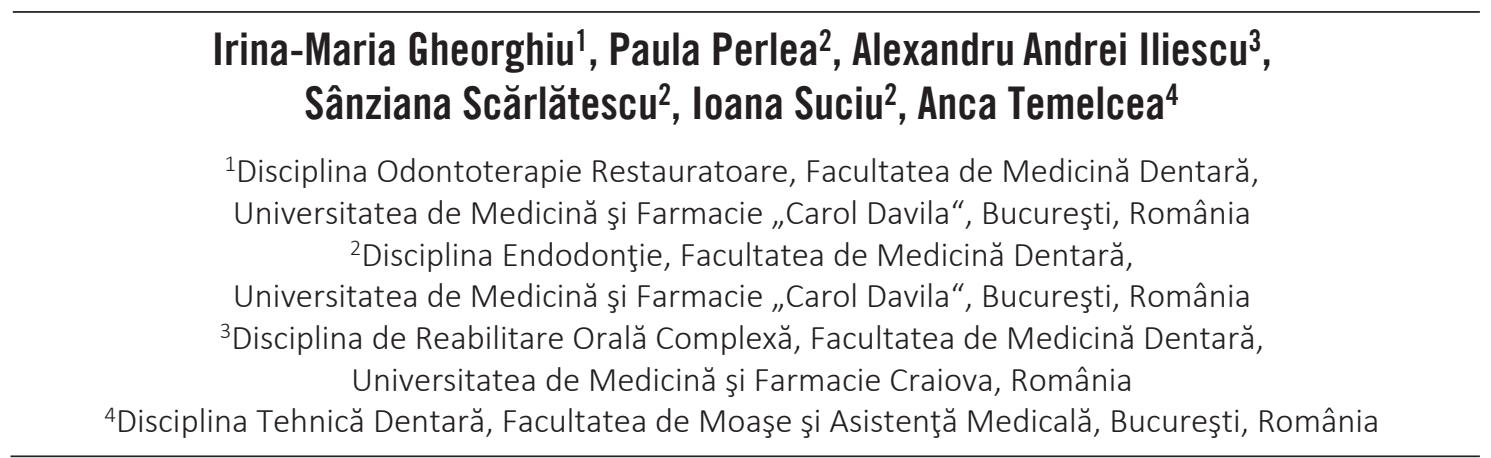

\begin{abstract}
This article reviews the current therapeutic attitude on dental caries prevention involving antimicrobial strategies, based on the modern definition of dental caries as a microbial disease. The most important and used prophylactic measures are: topical and systemic administration of fluorinated products, diet control and maintenance of a rigorous dental oral hygiene.
\end{abstract}

Keywords: dental caries, preventive measures, antimicrobial therapy

\section{REZUMAT}

Articolul de faţă trece în revistă modalităţiile actuale de prevenţie a cariei dentare, care au ca element comun strategiile antimicrobiene, întrucât concepţia modernă defineşte caria dentară drept o afecţiune microbiană. Cele mai importante şi utilizate măsuri profilactice sunt reprezentate de: administrarea topică şi sistemică de produse fluorurate, controlul aportului alimentar, precum şi realizarea şi menţinerea unei igiene orale adecvate.

Cuvinte cheie: carie dentară, măsuri profilactice, terapie antimicrobiană

Caria dentară este o afecțiune plurifactorială a țesuturilor dure ale dintelui. Prevalența acestei maladii este foarte mare, indiferent de sex sau vârstă.

Teoria etiopatogenică actuală a cariei dentare consideră că apariția şi evoluția unui proces carios reprezintă consecinţa acțiunii simultane şi cumulate a unui număr de trei factori principali, cunoscuți ca „triada Keyes“:

1. Gazda (terenul pacientului): lichidul bucal şi structurile dure dentare;

2. Alimentația (substratul alimentar);
3. Factorul microbian: microflora bucală cariogenă ce aderă la suprafețele dentare.

Practic, la ora actuală, caria dentară este considerată a fi o afecțiune microbiană a țesuturilor dure dentare. Procesul carios este rezultatul metabolismului microorganismelor bucale ce descompun şi fermentează substratul alimentar specific (hidrocarbonați), cu producerea de acizi, în special acid lactic. Aceştia determină demineralizarea țesuturilor dure dentare, practic, debutul procesului carios (1). 
Triada Keyes (terenul pacientului, substratul alimentar fermentabil şi microflora bucală cariogenă) explică în totalitate mecanismele ce duc la debutul unui proces carios, dar complexitatea tuturor factorilor implicați este mult mai mare. Ca atare, şi încercările de profilaxie şi tratament ale cariei dentare plecând de la îndepărtarea unuia dintre factorii cauzali nu sunt întotdeauna un succes, din cauza interrelațiilor multiple ce se stabilesc între aceştia. La aceasta participă şi complexitatea în sine a fiecărei categorii de factori etiologici.

Abordările moderne în privința profilaxiei cariei dentare utilizează măsuri terapeutice complexe şi combinate, cu adresabilitate simultană pe mai mulți factori cariogeni. Elementul comun îl reprezintă însă terapiile antimicrobiene în caria dentară, ce pleacă tocmai de la înțelegerea faptului că leziunea carioasă este o afecțiune microbiană. Efectele antimicrobiene pot fi directe (bactericid sau bacteriostatic) sau indirecte: prin acțiune pe substratul nutrițional (hidrocarbonate) sau asupra țesuturilor orale ale gazdei $(2,3)$.

Măsurile antimicrobiene actuale de prevenție a cariei dentare cuprind:

- administrarea de produse ce conțin fluor;

- controlul dietei;

- asigurarea unei igiene orale adecvate;

- imunizarea împotriva cariei dentare;

- utilizarea substanțelor antimicrobiene;

- determinarea clinică şi microbiologică a riscului de carie.

În cadrul acestui articol, vor fi prezentate: administrarea de produse fluorurate, importanța controlului dietei, precum şi a unei igiene orale adecvate ca strategii antimicrobiene în caria dentară.

\section{Administrarea de produse ce conţin fluor}

Una dintre cele mai cunoscute modalităţi de prevenție a cariei dentare este administrarea sistemică sau topică de produse ce conțin fluor. Efectul acestora este foarte documentat: fluorul din compoziția lor acționează la nivelul smalțului dentar, dar în aceeaşi măsură şi asupra microflorei bucale orale (4). Administrarea produselor ce conțin fluor face parte din măsurile de prevenție primară a cariei dentare. Aportul sistemic se face prin fluorizarea apei potabile, a sării utilizate în alimentație sau administrarea de comprimate cu fluor. La ora actuală, accentul se pune pe asigurarea unei concentrații permanente a ionilor de fluor la interfața placă dentară bacteriană-smalț (5). Acest lucru se realizează cu predilecție prin utilizarea produselor topice. Aportul de fluor local cuprinde geluri, paste de dinți, soluții de conțin fluorură de natriu în concentrație variabilă $0,05-0,2 \%$ sau fluorură de staniu în concentrații cuprinse între 2 şi $8 \%$.

Mecanismele de acțiune ale fluorului sunt:

I. În prezența ionilor de fluor se formează fluorapatita, care se substituie grupărilor de hidroxiapatită din structura smalțului. Țesutul dentar ce conține cristale de fluorapatită este mai puțin susceptibil la atacul cariogen bacterian. În situația aplicării topice de produse fluorurate, ionii de fluor prezenți în salivă substituie, de asemenea, şi sărurile solubile de magneziu şi carbonat ce au fost îndepărtate prin demineralizare. Astfel, formează din nou cristale de hidroxiapatită ce refac continuitatea smalțului afectat. Acest mecanism dublu de acțiune a fluorului este responsabil de refacerea leziunilor dentare necavitare.

II. Fluorul prezintă acțiune antimicrobiană prin inhibarea sintezei de glucoziltransferază, care are rol în elaborarea polizaharidelor extracelulare $\mathrm{cu}$ rol de adeziune şi rol nutrițional bacterian $(6,7,8)$. Fluorul inhibă şi dezvoltarea unor tulpini de microorganisme, în situația aplicărilor topice: efect antibacterian pe streptococul mutans, principalul agent microbian cariogen (9). Caracterul acțiunii antibacteriene a fluorului este o consecință a concentrației topice a acestuia: efectul este bacteriostatic la concentrații de $250 \mathrm{ppm}$ şi bactericid la $1.000 \mathrm{ppm}$.

\section{Controlul dietei}

Alimentația intervine în etiopatogenia cariei dentare astfel: este de dorit ca prin dietă să fie introdus în organism un aport corespunzător de nutrienți şi oligoelemente astfel încât țesuturile dentare să se formeze şi să se mineralizeze corespunzător pentru a face față activității cariogenice a microorganismelor orale. De asemenea, o dietă echilibrată determină un lichid bucal (saliva) cu flux, concentrație de electroliți şi proprietăți fizico-chimice adecvate şi carioprotectoare (este favorabil aportul alimentar de lactate, grăsimi) (10). Din păcate, rolul alimentației este însă unul mult mai important în mecanismele fiziopatologice de declanşare a unei carii dentare. Dieta, mai specific hidrocarbonatele fermentabile, sunt cel de-al doilea factor al triadei Keyes. 
Practic, leziunea carioasă este urmarea activităţii metabolice a microorganismelor aderate pe suprafața dentară, susținute de existența unui substrat alimentar fermentabil. Acest substrat îndeplineşte atât rol energetic, cât şi de adeziune pentru coloniile bacteriene. În urma proceselor metabolice, se eliberează acizi organici ce iniţiază atacul asupra prismelor de smalț acoperite de placă dentară bacteriană.

Controlul alimentației se referă la asigurarea unei diete echilibrate, cu un aport scăzut de hidrocarbonate. Supravegherea alimentației în raport cu apariția cariei dentare se referă la:

I. Controlul tipului de hidrocarbonat adus prin alimentație: practic, zaharoza (sucroza) prezintă cel mai mare potențial cariogen şi este sursa principală de nutrienți metabolici pentru microorganismele cariogene (streptococul mutans). Măsurile de carioprevenție includ înlocuirea în alimentaţie a zaharozei cu substanțe cu potențial cariogenic diminuat. Acestea pot fi produşi naturali (glucoză, fructoză, sorbitol) sau artificiali (zaharoză, ciclamat) (11). Unii dintre îndulcitorii artificiali posedă ei înşişi proprietăţi antibacteriene: zaharina inhibă dezvoltarea streptococului mutans şi nu poate fi utilizată ca resursă energetică pentru placa dentară bacteriană. Sorbitolul, manitolul sunt foarte puţin incluse în metabolismul plăcii, iar xilitolul nu poate fi catabolizat de către microorganismele din biofilm. Ca atare, efectul cariostatic apare consecutiv diminuării posibilităților de nutriție a microorganismelor.

II. Controlul cantității de hidrocarbonate ingerate: un aport scăzut de hidrocarbonate nu permite dezvoltarea unei plăci dentare bacteriene mature, ce posedă un metabolism înalt şi capacitate acidogenă mare (12).

III. Controlul frecvenței ingestiei de hidrocarbonate: din păcate, aportul frecvent de hidrocarbonate în alimentație asigură un rezervor permanent de energie pentru bacteriile orale ataşate pe suprafetele dentare.

IV. Controlul gradului de rafinare al hidrocarbonatelor: consistența alimentelor, gradul de aderență

\section{BIBLIOGRAFIE}

1. Popa M.P., D. Bodnar, Varlan M.C. Manual de odontoterapie restauratoare, Ed. Univ. Carol Davila, Bucureşti, 2006, 151-205. la suprafețele dentare, modul de prelucare (de exemplu: zahăr brut sau zahar rafinat), aciditatea băuturilor dulci.

Toate aceste caracteristici fizico-chimice ale zaharurilor introduse prin alimentație pot influența atât în sens carioprotector, cât şi cariofavorizant procesele metabolice ale microorganismelor din placa dentară bacteriană. Mecanismele sunt directe şi indirecte: spre exemplu, un aliment cu duritate mare şi aderenţă scăzută nu se ataşează cu uşurinţă de suprafețele dentare datorită proprietăților sale fizico-chimice; în acelaşi timp însă, în cursul masticației acestui aliment, este produs un flux salivar abundent, care scade clearance-ul alimentului respectiv în cavitatea orală şi exercită astfel o acțiune carioprotectoare.

\section{Asigurarea unei igiene orale adecvate}

Aceasta include utilizarea pastelor de dinți cu conținut de fluor (discutată anterior), utilizarea aței interdentare ("dental floss"), precum şi a apelor de gură.

Periajul dentar şi celelalte manopere de igienă dentară au ca efect:

I. îndepărtarea mecanică a plăcii dentare bacteriene de pe suprafaţa dinţilor şi a resturilor de alimente care vor fi înglobate ulterior în aceasta.

II. utilizarea pastelor de dinţi scade încărcătura microbiană şi facilitează dezintegrarea coloniilor microbiene, odată cu stimularea proceselor de remineralizare.

Manoperele terapeutice de prevenție a cariei dentare includ şi sigilarea şanturilor şi fosetelor imediat posteruptiv pentru a reduce nişele ce pot fi colonizate bacterian $(13,14)$. Utilizarea în acest scop a materialelor cu conţinut şi eliberare prelungită de fluor amplifică efectul carioprotector.

\section{Mențiune}

Toți autorii au contribuție egală în realizarea acestui articol.

Conflict of interest: none declared Financial support: none declared

2. Rowson C., Townsend R. Biofilms: prevention and treatment. Br J Hosp Med (Lond). 2016 Dec 2;77(12):699703. 
3. Chałas R., Wójcik-Chęcińska I., Woźniak M.J., Grzonka J., Święszkowski W., Kurzydłowski K.J. Dental plaque as a biofilm - a risk in oral cavity and methods to prevent. Postepy Hig Med Dosw (Online). 2015 Oct 13;69:1140-8.

4. Iliescu A., Gafar M. Cariologie şi odontoterapie restauratoare. Ed. Medicală, Bucureşti, 2011, 31-57.

5. Steinberg D., Friedman M. Sustained-release drug delivery of antimicrobials in controlling of supragingival oral biofilms. Expert Opin Drug Deliv. 2017 Apr;14(4):571-581.

6. Pleszczyńska M., Wiater A., Bachanek T., Szczodrak J. Enzymes in therapy of biofilm-related oral diseases. Biotechnol Appl Biochem. 2017 May;64(3):337-346.

7. Arthur R.A., Cury A.A., Graner R.O., Rosalen P.L., Vale G.C., PaesLeme A.F. et al. Genotypic and phenotypic analysis of $S$. mutans isolated from dental biofilms formed in vivo under high cariogenic conditions. Braz Dent J. 2011; 22:267-74.

8. Beighton D., Gilbert S.C., Clark D., Mantzourani M., Al-Haboubi M, Ali F. et al. Isolation and identification of bifidobacteriaceae from human saliva. Appl Environ Microbiol. 2008; 74:6457-60.

9. Nijampatnam B., Casals L., Zheng R., Wu H., Velu S.E. Hydroxychalcone inhibitors of Streptococcus mutans glucosyl transferases and biofilms as potential anticaries agents. Bioorg Med Chem Lett. 2016 Aug 1;26(15):3508-13.
10. Moynihan P.J. The role of diet and nutrition in the etiology and prevention of oral diseases. Bull World Health Organ. 2005; 83(9):694-699

11. Broad E.M., Rye L.A. Do current sports nutrition guidelines conflict with good oral health?. Gen Dent. 2015 Nov-Dec; 63(6):18-23.

12. Kang M.S., Oh J.S., Lee H.C., Lim H.S., Lee S.W., Yang K.H., Choi N.K., Kim S.M. Inhibitory effect of Lactobacillus reuteri on periodontopathic and cariogenic bacteria. J Microbiol. 2011; 49(2):193-199.

13. Lalloo R., Kroon J., Tut O., Kularatna S., Jamieson L.M., Wallace V., Boase R., Fernando S., Cadet-James Y., Scuffham P.A., Johnson N.W. Effectiveness, costeffectiveness and cost-benefit of a single annual professional intervention for the prevention of childhood dental caries in a remote rural Indigenous community. BMC Oral Health. 2015 Aug 29;15:99.

14. Wright J.T., Tampi M.P., Graham L., Estrich C., Crall J.J., Fontana M., Gillette E.J., Nový B.B., Dhar V., Donly K., Hewlett E.R., Quinonez R.B., Chaffin J., Crespin M., lafolla T., Siegal M.D., Carrasco-Labra A. Sealants for Preventing and Arresting Pit-and-fissure Occlusal Caries in Primary and Permanent Molars. Pediatr Dent. 2016; 38(4):282-308. 